\title{
Librarian for Latin American and Caribbean Studies in U.S. Academic and Research Libraries
}

\section{A Content Analysis of Position Announcements, 1970-2007}

\section{By Jesús Alonso-Regalado and Mary K. Van Ullen}

The present research investigates the evolving requirements, roles, and responsibilities of the Latin American and Caribbean studies librarian. Content analysis was used to study 94 position announcements published from 1970 to 2007. Variables were examined from the following categories: position description, educational background, work experience, technology skills, languages, personal traits, duties, and subject responsibilities. Cross tabulations and chi-square tests were executed to determine the statistical significance of relationships between variables. An advanced degree in a related subject field is expected by employers. Strong Spanish language abilities are required, and a working knowledge of Portuguese is highly desirable. The average number of duties per announcement has increased over time, reflecting the evolution of the position from being narrowly specialized to being more diversified. The Latin American and Caribbean studies librarian may also be responsible for additional subjects, in particular Iberian studies.

Jesús Alonso-Regalado (jalonso@uamail albany.edu) is Bibliographer for Latin American, Caribbean, and U.S. Latino Studies, and Mary K. Van Ullen (mvanullen @uamail.albany.edu) is Bibliographer for Business, Economics, Geography, Planning, and Law, University Library, University at Albany, State University of New York.

Submitted November 1 1,2008; tentatively accepted January 26, 2009, pending revision; revised and submitted February 17, 2009, and accepted for publication.
T atin America has always been a region of considerable importance to the $\mathcal{L}$ United States because of its proximity, economic and political interrelations, shared history, and immigration. This interest is reflected in a letter signed by more than 360 Latin American experts that was sent to then Senator Barack Obama during the final days of the 2008 U.S. presidential campaign, calling for improved U.S.-Latin America relations in "a new period of hemispheric understanding and collaboration for the common welfare."

U.S. universities have a long tradition of Latin American and Caribbean studies (LACS), stemming from Cold War-era tensions and accelerated by the Cuban Revolution. In 1979, Lozano and Mesa-Lago stated, "The funding and development of international studies at U.S. universities (particularly in the Latin American area) peaked in the 1960s as a result of domestic and foreign events." Since then, interest in the study of Latin America in the United States has grown significantly, as can be seen in the increasing number of academic programs dealing with Latin America, the increasing number of students enrolled in 
these programs, and the volume of scholarly research and publications on topics pertaining to the area. According to The College Blue Book, in 1972 there were 120 LACS academic programs, and the number increased steadily to 146 programs in 2001. Growth increased sharply over the next several years to 204 such programs in $2009 .{ }^{3}$ Data from the National Center for Education Statistics show that the combined number of bachelor's, master's, and doctoral degrees in Latin American studies conferred by U.S. institutions of higher education has nearly doubled from 1970-71 to 2006-7, climbing from 431 to 834 degrees. ${ }^{4}$ These trends will most likely continue because of demographic changes in the population that influence demand for programs of study in higher education. The U.S. Census Bureau predicts that Hispanics will grow from 12.5 percent of the U.S. population in 2000 to 24.4 percent in $2050 .^{5}$

The significance of Latin American and Caribbean studies as an area of research, given its interdisciplinary nature, can be demonstrated by the growth in the number of dissertations and theses published. A search of the Dissertations and Theses: A\&I database using "Latin America" or "Caribbean" as a subject showed an increase in the number of dissertations and theses published from 908 during the 1970 s to 3,696 from 2000 to 2008 . There also is a substantial increase in the publication output from Latin American countries. According to the Regional Centre for the Promotion of Books in Latin America and the Caribbean (CERLALC), from 2001 to 2006 the number of new materials from Latin American countries that were assigned an International Standard Book Number grew from 64,640 to 99,566, a 54 percent increase. ${ }^{6}$ All these factors have made the study and research of Latin America and the Caribbean more prevalent in U.S. higher education institutions.

While libraries have historically collected materials covering the cultures, languages, and literatures of Latin America, the rise of area studies programs broadened collections to include a multidisciplinary perspective. As Stern explained, "With these programs came the systematic development of collections to support instruction and research, and of professional organizations to coordinate and guide this process of collection-building." ${ }^{.7}$ The Seminar on the Acquisition of Latin American Library Materials (SALALM), founded in 1956, is the key professional organization for LACS librarians and book dealers.

With the growth of area studies programs in the 1960s and 1970s, universities began hiring subject specialists in academic libraries. Prior to this, collections in academic libraries were developed mainly by faculty. Early area studies librarians concentrated heavily on collection-building tasks, but over time their role has evolved. As Jakubs discussed, "Once almost exclusively focused on materials selection, the responsibilities of the librarian engaged in collection development now extend to the creation and maintenance of websites, intensive faculty outreach, teaching, specialized reference service, fund-raising, and other tasks." "Evidence about the changing role of the LACS librarian over time remains largely anecdotal. This study adds to the body of literature by using content analysis to document changes in the scope of positions within a narrowly defined area of librarianship.

The present research examines the requirements and responsibilities of the LACS librarian as reflected in position announcements between 1970 and 2007. Prior research has been limited in scope, detail, and time coverage, and generally has not been specific to LACS librarians. Content analysis of job announcements provides essential information about the evolution of the positions over time, the nature of the job market, and predictions of employment trends. Findings from this study would be useful to library students interested in pursuing LACS careers, library school faculty responsible for curriculum decisions, library administrators who define the scope of bibliographer positions, and LACS librarians as they reflect on developments within their profession.

This investigation was framed by the following questions:

- How were these positions described from 1970 to 2007?

- What skills, experience, and abilities do institutions seek in LACS librarians?

- What and how many duties are required for these positions?

- What and how many subject responsibilities are required for these positions?

- What trends can be observed in the job announcements over time? Which of the changes are statistically significant?

- How does the institutional type shape the nature of the position?

- What is the value of experience in relation to some duties?

- Were some duties or subject responsibilities commonly found together? Were some subject responsibilities and languages commonly found together?

\section{Literature Review}

The literature covering LACS librarianship has mainly dealt with topics such as selecting materials, analyzing particular reference research resources, and general overviews focusing on building Latin American collections. A 2007 contribution to this last topic is the chapter "Latin American Collections" in Building Area Studies Collections by Shirey. ${ }^{9}$ Also in 2007, Mazurkiewicz and Potts published a research article presenting the results of a national survey on how 
new generations of users are researching Latin America, a topic not previously discussed in the literature. ${ }^{10}$

Other issues pertaining to LACS librarianship remain to be explored in detail. Some articles examine the role of LACS librarians from a historical point of view while some attempt to predict the future of these positions. Most articles are personal analyses, opinion pieces, descriptive accounts, or literature reviews, and do not provide empirical research.

A few studies used surveys to examine the role of area studies librarians. Smith interviewed 93 specialists employed in 10 Association of Research Libraries (ARL) institutions. ${ }^{11}$ The author noted a trend to hire individuals with highly specialized training and subject expertise to fill specialist positions, but his findings included little quantitative data about the specifics of the specialist position responsibilities. Another examination of the role of area studies librarians was undertaken by Stueart, who surveyed area studies librarians, library administrators, and faculty in departments and programs served by the librarians. ${ }^{12}$ In Stueart's study, basic information about gender and subject area was collected for 126 librarians, and, of those, 26 were Latin American studies librarians. More specific information, including education, languages spoken, and research interests, was collected for a small subset of 30 respondents, only 3 of whom were Latin American studies librarians. The focus of Stueart's research was the divergent perception of the responsibilities of the area studies librarian by the faculty, library administrators, and librarians themselves.

A significant compilation of survey research was presented at the Future of Area Librarianship Conference held in $1995 .{ }^{13}$ Questionnaires from 187 area studies librarians were analyzed to report on background qualifications, job functions, and professional development. Responses from 26 Latin American studies librarians were included. The survey questions were general in nature, and participants at the conference expressed interest in having more detailed information about the nature of job duties for area librarians.

A survey that focused specifically on Latin American research collections in the United States was presented in 1969 by Miller and Fort. ${ }^{14}$ This survey collected information on the size and nature of the collection, staffing levels, and budgetary support. It did not attempt to address specifics about the LACS librarians themselves.

Many researchers have employed content analysis as a tool for examining job advertisements to develop a picture of the work performed by academic librarians over time. Their studies typically include analyses of position types, geographic locations, education, experience, salary, and skills, but do not include much detail about the specific duties and responsibilities entailed. Rayman examined a large number of job announcements appearing in Library Journal during the 1970s. ${ }^{15}$ His study included position announcements for 85 bibliographer jobs, and those jobs were listed primarily in the middle years of the decade, declining substantially by 1979 . Wells studied job postings found in Library Journal, ALA Bulletin/American Libraries, College and Research Libraries, and College and Research Libraries News (CむRL News) from 1959 through 1979. ${ }^{16}$ She looked only at advertisements that appeared at five-year intervals during this span. Wells' data included a category for subject specialist positions, and her data concurred with that of Rayman, finding a peak demand for these positions in 1974. Wright looked at a large number of job advertisements published in American Libraries, College and Research Libraries, and Library Journal from 1980 to $1984 .{ }^{17}$ Her study included both public and academic library positions, with 67.2 percent of the advertisements falling into the latter category. Reser and Schuneman used content analysis to examine jobs advertised in 1988 in American Libraries, CむRL News, Library Journal, and the Chronicle of Higher Education. ${ }^{18}$ They did not include a position category for collection development, bibliographers, or subject specialists. While one may wonder why no such positions were included in Reser and Schuneman's study, determining how those authors categorized those positions is impossible. This study was updated by Beile and Adams, who looked at positions listed in those same journals in $1996 .{ }^{19}$ Beile and Adams saw an overall decrease in the number of academic library jobs advertised, but also found 6 percent to be in collection development. Lynch and Smith applied content analysis to a sample of job announcements spanning a twenty-five year period from 1973 through 1998 that appeared in C $b R L$ News. ${ }^{20}$ Many of the subject specialist positions were combined with other significant responsibilities, in particular with reference. Lynch and Smith concluded that "jobs in academic librarianship were shifting from the traditional, functional specialist positions to more expansive and complex jobs," that is, positions with combined responsibilities. ${ }^{21}$ Starr examined a sample of job advertisements for all types of libraries in 1983 and 2003 taken from American Libraries and Library Journal. ${ }^{22}$ Like Beile and Adams, Starr also found a decrease in the total number of job advertisements over time. She noted that this decrease in print advertisements did not necessarily imply a declining number of library positions, given the greater importance of electronic-only advertising.

Several researchers have employed content analysis to look at advertisements for subject specialist and collection development positions. In his 1993 article, Robinson examined advertisements appearing in C $\triangleleft R L$ News from 1980 through 1991 and selected those for which "collection development," "collection management," "selection," or "bibliographer" appeared in the job title. ${ }^{23} \mathrm{He}$ did not include positions in which these functions were listed within the body of the advertisement but not in the job title. Robinson 
observed a fairly steady increase in the number of these types of advertisements published throughout the 1980s. White analyzed subject specialist positions appearing from 1990 through 1998 in American Libraries, C dRL News, and the Chronicle of Higher Education. ${ }^{24}$ He focused on academic business, social science, and science librarian positions and found that the number of position advertisements for social sciences remained fairly constant throughout the period. Haar examined advertisements for bibliographer positions in college and university libraries that appeared in the Chronicle of Higher Education between March and October $1990{ }^{25}$ Haar's study included only a small number of job advertisements, and the short period of time covered provides a snapshot of employers' requirements at that time. A more specific study that focused on advertisements for academic library area studies or language-specific library positions was undertaken by Knowlton. ${ }^{26}$ This study looked at job postings advertised from January 2001 through May 2002 in American Libraries and in the SALALM Newsletter. Of the 28 advertisements identified during this time, only 4 were for Latin American and Iberian area studies positions.

To date, no study has been published that uses content analysis to examine a large number of position announcements for LACS librarians over a broad span of time. Furthermore, no study has looked in detail at this type of position to include a wide range of variables, including position characteristics, education, experience, skills, duties, and subject responsibilities. This research contributes to the body of literature by providing an extensive and quantitative analysis of LACS librarian job announcements spanning several decades.

\section{Research Methods}

Three sources of job advertisements were examined for this study: CむRL News, the SALALM Newsletter, and LALA-L, the Latin Americanist Librarians' electronic discussion list for SALALM. C bRL News has been a major venue for the publication of academic library positions over the past several decades. Both the SALALM Newsletter and LALA-L have been primary tools for advertising LACS librarian positions. The sources and associated numbers of advertisements by publication period are shown in table 1 .

Issues of C $b R L$ News and the SALALM Newsletter were examined for job advertisements from 1970 through 2007. The first job advertisement appeared in C\&RL News in 1975 and in the SALALM Newsletter in 1976. LALA-L was launched in August 1991, but the postings were not archived until April 1995, so only job advertisements appearing after this date are included in the study. Access to LALA-L is restricted to members of SALALM. Within these three sources, all appropriate job advertisements were included, thus providing a census of the position descriptions over the time period covered.

Two leading sources of advertising for academic library positions are the Chronicle of Higher Education and JobLIST, a service of American Libraries, and C $b R L$ News. These sources were not utilized in the present study for logistical reasons. The Chronicle of Higher Education is published in both print and electronic form. Both JobLIST and the electronic version of the Chronicle do not permanently archive job advertisements, and they are removed after a few months. The Chronicle is a weekly publication, archived on microfilm. Reviewing decades' worth of past issues for job announcements for this research project would have been prohibitively time-consuming.

Job advertisements were examined for duplication, and, in the case of duplicates appearing in multiple sources, all sources were consulted for the purpose of coding them, but the position was only counted once. If a position was reposted unchanged within a year of the original publication date, it was eliminated. However, if substantive modifications were evident, the job advertisement was added to the study.

Table 1. Sources of Advertisements by Publication Period

\begin{tabular}{|c|c|c|c|c|c|c|c|c|}
\hline \multirow[b]{2}{*}{ Source } & \multicolumn{2}{|c|}{$\begin{array}{c}1970-89 \\
n=25\end{array}$} & \multicolumn{2}{|c|}{$\begin{array}{c}1990-99 \\
n=35\end{array}$} & \multicolumn{2}{|c|}{$\begin{array}{c}2000-2007 \\
n=34\end{array}$} & \multicolumn{2}{|c|}{$\begin{array}{c}\text { Total } \\
n=94\end{array}$} \\
\hline & $\#$ & $\%$ & $\#$ & $\%$ & $\#$ & $\%$ & $\#$ & $\%$ \\
\hline SALALM Newsletter & 6 & 24.0 & 13 & 37.1 & 2 & 5.9 & 21 & 22.3 \\
\hline C\&RL News & 13 & 52.0 & 3 & 8.6 & 2 & 5.9 & 18 & 19.1 \\
\hline LALA-L \& C\&RL News & 0 & 0.0 & 0 & 0.0 & 6 & 17.6 & 6 & 6.4 \\
\hline SALALM Newsletter \& LALA-L & 0 & 0.0 & 5 & 14.3 & 1 & 2.9 & 6 & 6.4 \\
\hline All sources & 0 & 0.0 & 0 & 0.0 & 1 & 2.9 & 1 & 1.1 \\
\hline
\end{tabular}


The advertisements had to mention both collection development as a duty and LACS as a subject responsibility for inclusion in the study. This also included positions where only certain Latin American countries or regions were mentioned rather than LACS as a whole. Positions with additional significant responsibilities, such as reference or management, were included provided that they also entailed selection for the LACS collection. Only full-time jobs located in the United States were considered.

A total of 94 unique advertisements were identified for inclusion in the study. The LALA-L discussion group yielded 28 exclusive advertisements, and 21 and 18 advertisements each were found exclusively in the SALALM Newsletter and in CむRL News, respectively. Twenty-six announcements were found in 2 sources, and 1 advertisement appeared in all 3.

Descriptive content analysis was performed on each job advertisement using the content analysis methodology described by Neuendorf as "the systematic, objective, quantitative analysis of messages characteristics." ${ }^{\text {27 }}$ As a first step, the researchers developed a set of variables and values reflecting the position description, requirements, duties, and subject responsibilities. These variables and values were used to develop a coding sheet as described by Hall-Ellis. ${ }^{28}$ In the present study, each job advertisement was examined for the presence of language corresponding to the variables and values developed. To examine the way that these positions have evolved over time, job advertisements also were grouped into three time periods: 1970-89 (25 positions), 1990-99 (35 positions), and 2000-2007 (34 positions).

Because only six positions were advertised in the 1970s, they were grouped with positions appearing in the 1980s. As Haar pointed out, "It was during the 1960s, however, that bibliographers appeared in major libraries nationwide." 29 Not until the 1970s did the position of the bibliographer start to become more commonly advertised as it achieved general acceptance in academic libraries.

To standardize the coding, two tools were created to form a single codebook. A coding sheet was developed to identify variables and assign corresponding values. A dictionary was created to define more ambiguous terms to help provide consistency in the interpretation of the job postings when coding. The set of variables and values was developed by examining a sample of job advertisements, reviewing the literature, and drawing on background knowledge of the subject. This set was further refined during the course of the data analysis. Both authors analyzed all job announcements.

If the logical operator "or" was used between two variables found in a job announcement, the variable was assumed to be positive for both. For example, if a posting stated that the applicant should speak Spanish or Portuguese, both languages would be counted as positive.

Data were entered into the Statistical Package for the
Social Sciences (SPSS). Descriptive statistical information was generated in the form of frequencies and cross tabulations. Pearson's chi-square values were calculated to determine the statistical significance of relationships between variables. A $p<.05$ level of significance was used for this study. Chi-square tests were run to determine the association between all job advertisement characteristics and the time periods in which the advertisements were published. This was done to investigate changes in advertisement content over time, all duties listed in the advertisements to identify duties commonly found together, and all subject responsibilities and language requirements to identify those commonly found together. The statistical tests were not valid for many of the variables because of the distribution of the data among the cells. For others, the tests were valid but the associations were not significant at the $p<.05$ level.

\section{Findings}

The findings from this research project are organized into three categories: position description characteristics, requirements, and duties and subject responsibilities. The data are provided in the appendix.

\section{Position Description Characteristics}

A job title may be seen as a brief summary of a position's role within an organization. As reported in section A of the appendix, the most common job title was "Librarian," which appeared in 46 advertisements (48.9 percent), followed by "Bibliographer," which appeared in 21 advertisements (22.3 percent). Fourteen job postings (14.9 percent) listed "Head/ Director" as the position title. "Subject Specialist" was the title for 10 positions (10.6 percent), and "Curator" was the title of 3 positions (3.2 percent). Over time, position titles have changed. The title "Bibliographer" has declined in popularity. Nearly half (44 percent) of the jobs advertised from 1970 to 1989 used this title while it was used on only 8.8 percent of those advertised from 2000 to 2007. This term has largely been replaced by the title "Librarian," the use of which grew from 24 percent from 1970 to 1989 to 64.7 percent from 2000 to 2007 .

Libraries were categorized by institutional type as being part of public universities (61 positions), private universities (20 positions), or research and specialized libraries (13 positions). The latter category includes the Library of Congress, Inter-American Development Bank, New York Public Library, Organization of American States, Radio Martí, and the John Carter Brown Library. Unless otherwise noted, this category is included under the term academic libraries. Most of the positions (75.5 percent) were advertised by Association of Research Libraries members. 
Institutions were divided into four geographic areas using the classification categories on the Library and Information Technology Association's job webpage (www .lita.org/ala/mgrps/divs/lita/litaresources/litajobsite/litajob site.cfm). Overall, job advertisements were fairly equally distributed around the country, with 31 appearing for positions in the South, 25 in the Northeast, 18 in the Midwest, and 20 in the West. However, data show a shift in the distribution of job advertisements over time. In the 1970s and 1980s, 68 percent of the jobs advertised were located in the Midwest and West, while the Northeast and the South accounted for 76.5 percent of the jobs offered in 2000-2007.

Faculty status and tenure are difficult variables to analyze using content analysis because these terms lack usage standardization across different institutions. For this reason, an advertisement was only counted as having faculty status if the term faculty status, faculty appointment, or Assistant/ Associate/Full Professor appeared. To be counted as a tenure track position, the term tenure, continuing appointment or continuing employment had to be present. Faculty status was indicated in 14 advertisements (14.9 percent). Tenure track was indicated in 17 (18.1 percent) of the cases. Both variables were positive in only 8 positions.

Information about how a position is placed within the organizational structure can be drawn from looking at its reporting line. Only 37 (39.4 percent) of the advertisements analyzed listed the reporting line for the position. They included 9 area or international studies positions (9.6 percent), 8 collection development positions (8.5 percent), 5 public services positions (5.3 percent), 4 Latin America library or unit positions (4.3 percent), and 11 "other" positions (11.7 percent). This last category included 4 positions in which the employee had dual reporting lines.

Advertisements were also examined for salary information. Only 7 (7.4 percent) of the advertisements contained no reference to salary. In 74 cases (78.7 percent), dollar amounts were mentioned in the advertisements, but the information given was in the form of minimums or salary ranges instead of a specific starting salary for the position. In some cases, several ranges were given depending on the rank at which the applicant would be hired. Thirteen postings (13.8 percent) stated that the salary was commensurate or competitive but did not state a numerical value.

The data show a trend over time to replace specific salary information with a more general statement that the salary would be commensurate or competitive. No job advertisements appearing from 1970 through 1989 contained the "commensurate/competitive" language, but from 2000 through 2007 it appeared in 11 cases, which represents 32.4 percent of the positions advertised in this period. Information about salary in the form of minimums or salary ranges decreased from 92 percent in 1970-89 to 55.9 percent in 2000-2007.

\section{Requirements}

Requirements were identified in the areas of academic background, background knowledge, work experience, technology skills, language skills, and personal traits (see section $\mathrm{B}$ of the appendix). Seventy-four positions (78.7 percent) required a master of library science (MLS) degree, while an additional 12 positions (12.8 percent) stated that an MLS was preferred. Fifty-seven positions (60.6 percent) more specifically required an American Library Association (ALA)-accredited MLS, and an additional 11 (11.7 percent) preferred it. Only 22 advertisements (23.4 percent) mentioned that an MLS equivalent was a requirement while 3 cases (3.2 percent) specified it as a preference.

Subject knowledge could be satisfied in a variety of ways. An advanced degree in a related field was required in 28 cases (29.8 percent) and preferred in 35 cases (37.2 percent). Most of the job advertisements in the present study were quite specific about the nature of the advanced degree required. Of the 94 total job postings, 41.5 percent stipulated that the advanced degree be in Latin American studies or with a Latin American emphasis. Another 21.3 percent mentioned the degree should be in a relevant subject. Only 2.1 percent allowed for a degree in the social sciences or humanities, and another 2.1 percent did not specify a particular field. A noticeable growth in the number of positions that required or preferred an advanced degree in a related field is apparent over time. In 1970-89, 14 positions (56 percent) required or preferred an advanced degree, while in 1990-99 this requirement or preference was stated in 25 cases (71.4 percent). In 17 cases (18 percent), a PhD was preferred, but was only required in 2 .

Only 12 positions (12.8 percent) required an undergraduate degree in a related field - this was preferred for an additional 3 positions. Some advertisements called for additional subject-related education without specifying a degree requirement, categorized here as "coursework in related field." Examples of such expressions include "educational background," "relevant education," and "comparable academic background." This was required or preferred in 32 cases (34 percent).

Along with formal educational requirements, the advertisements frequently required fields of knowledge specific to LACS librarian positions. Knowledge of Latin American history, culture, and society was required in 32 cases (34 percent) and in 18 (52.9 percent) of all the positions advertised between 2000 and 2007. Far fewer positions-only 15 (16 percent) — required the knowledge of specialized Latin American reference tools.

The Latin American publishing industry has unique characteristics that affect collection development. A total of 30 positions (31.9 percent) specifically required knowledge of the Latin American publishing industry. Over time, the 


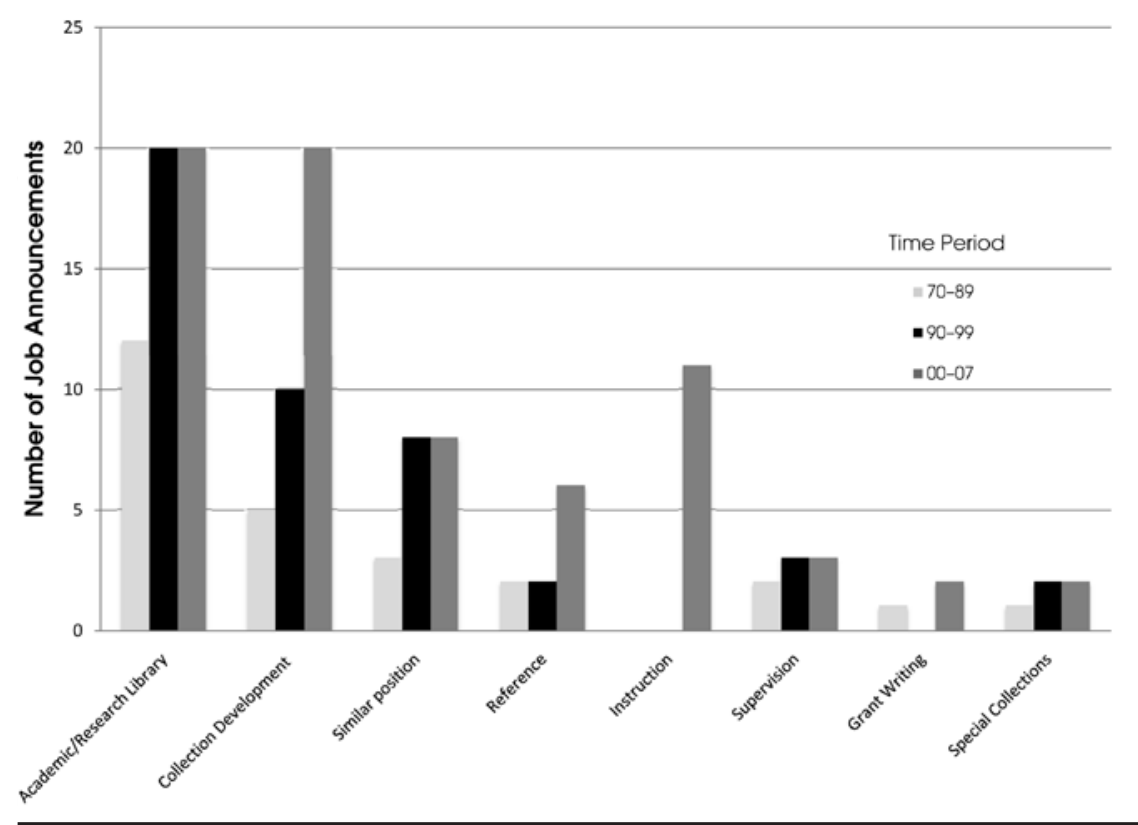

Figure 1. Type of Required Prior Experience by Time Period

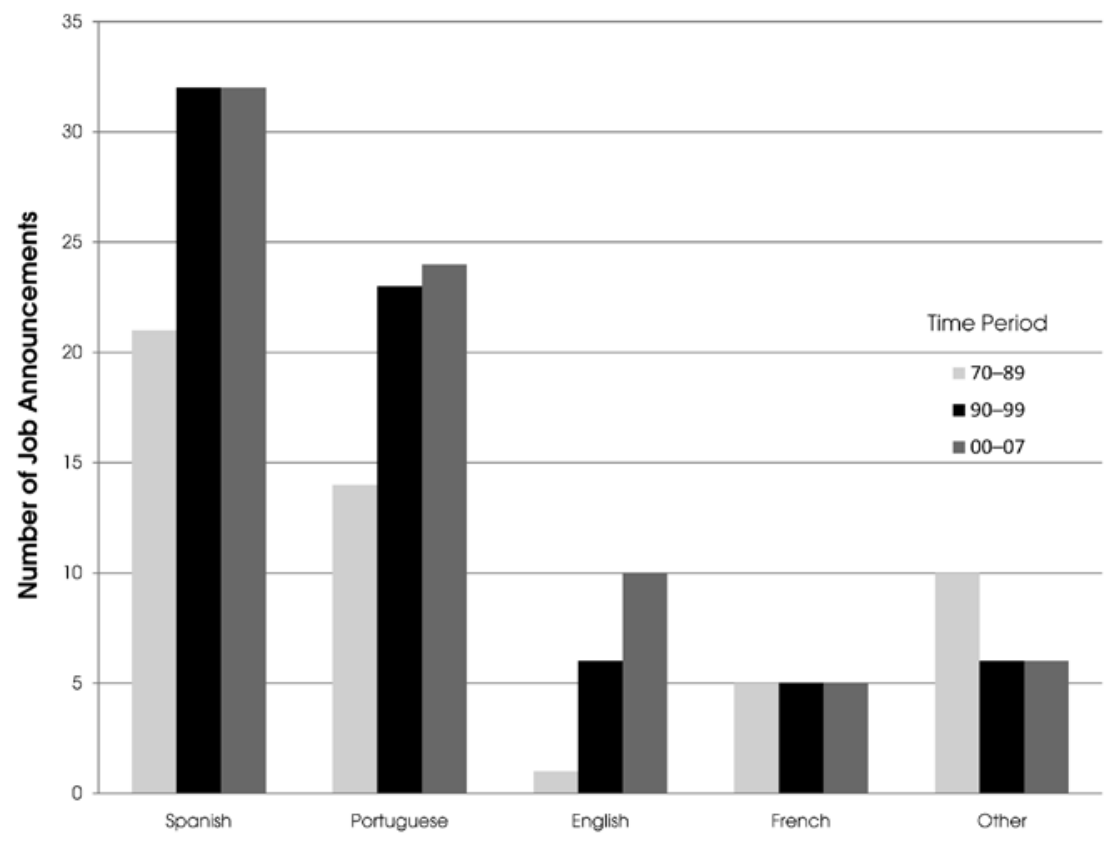

Figure 2. Language Skill (Required + Preferred) by Time Period are not reflected in this figure. The requirement for experience in an academic or research library has increased from 12 positions (48 percent) advertised in $1970-89$ to 20 (58.8 percent) in 2000-2007. Likewise, required experience in a similar position increased from 3 cases (12 percent) in 1970-89 to 8 (23.5 percent) in $2000-2007$. The number of positions requiring collection development experience climbed during each of the three time periods, going from 5 cases (20 percent) in 1970-89 to 10 cases (28.6 percent) in 1990-99 and 20 cases (58.8 percent) in 2000-2007.

The growing trend of libraries providing information literacy instruction is reflected in the position descriptions. From the 1970s through the 1990s, none of the advertisements required experience in instruction, while this was required in 11 (32.4 percent) of the advertisements published from 2000 through 2007.

The most requested types of experience were experience in academic or research libraries, collection development, experience in similar positions, reference, and instruction. Fewer advertisements mentioned experience in supervision, grant writing, or special collections.

One of the key factors affecting libraries over the past few decades has been the rise of computer technology and automation, profoundly altering the work of every employee. A total of 28 positions (29.8 percent) specifically required computer and information technology skills in general. Of the positions advertised in 1970-89, only 2 (8 percent) required these skills. This grew to 15 advertisements (44.1 percent) in 2000-2007. Surprisingly few advertisements included reference to more spedemand for this knowledge has increased from being present in 12 percent of positions advertised in 1970-89 to 44.1 percent in 2000-2007.

The types of work experience sought by employers reflect changes over time in job responsibilities for LACS librarians. Figure 1 shows the types of required prior experience listed in job advertisements by time period; position advertisements that listed types of experience as preferred cific technology-related skills such as Web design, creation and management of digital projects, or online searching.

Latin America is a region with a rich diversity of languages; the most common languages are Spanish, Portuguese, English, and French. This is reflected in the job advertisements for LACS librarians. Figure 2 shows the number of advertisements by time period that included language skills as being either preferred or required. English 


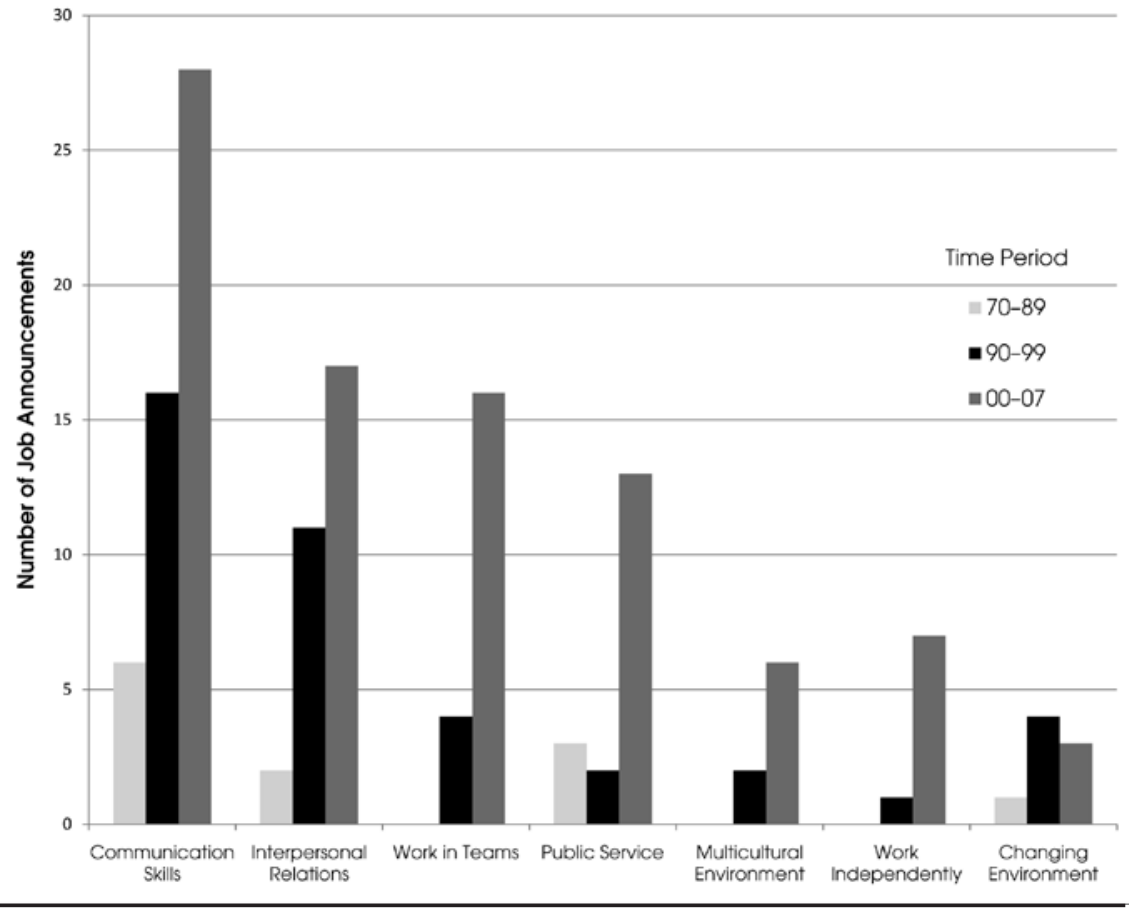

Figure 3. Personal Traits by Time Period

job advertisements often call for certain types of personal characteristics. Over time, more of these traits were being sought from applicants. Figure 3 shows the frequency of personal traits that appeared in the job postings in each of the three decades studied. The most highly demanded trait in all time periods was communication skills (oral and written). Roughly half (53.2 percent) of the job advertisements mentioned this ability. In 1970-89, 6 advertisements (24 percent) requiring communication skills were published; this increased to 28 (82.4 percent) in 2000-2007. The association between communication skills and time period was statistically significant $\left(\mathrm{x}^{2}=20.955, \mathrm{df}=2, p=.000\right)$.

Similar trends were observed over time for interpersonal relations, the ability to work collaboratively in teams, and a public service (user-centered) perspective. In $1970-89,2$ cases (8 percent) requiring interpersonal relations were published; this increased to 17 (50 per-

language skills were expected in only 1 case (4 percent) in 1970-89. In 1990-99, English was included in 6 (17.1 percent) cases, rising to 10 (29.4 percent) in 2000-2007. Spanish and Portuguese exhibited a similar pattern, showing a steep increase from the 1970-89 period to the 1990s, and remained essentially steady in 2000-2007.

When languages were included in job advertisements, they were mentioned either as a requirement or as a preference. Spanish language was the most frequently required, appearing in 82 cases ( 87.2 percent). Only 3 cases (3.2 percent) listed Spanish as preferred. In contrast, Portuguese was required in 38 cases (40.4 percent), but was preferred in 23 cases (24.5 percent). English was required in only 17 cases (18.1 percent).

The data were also analyzed for the level of language skills specified. A total of 71 cases (75.5 percent) required fluency in Spanish. The demand for fluency in Spanish increased from 16 (64 percent) in the 1970-89 period to 30 (88.2 percent) in 2000-2007. Working knowledge was only required in 8 cases ( 8.5 percent), followed by reading knowledge in 6 cases ( 6.4 percent). Fewer advertisements required fluency in Portuguese, with 20 cases (21.3 percent) demanding it. This requirement rose from 3 (12 percent) in the earliest period to 11 (32.4 percent) in the most recent. More advertisements required a lesser level of Portuguese language skills. A working knowledge was required in 24 cases (25.5 percent), and a reading knowledge in 17 cases (18.1 percent).

In addition to specific work experience and skills, cent) in 2000-2007. The relationship between this variable and time period was statistically significant $\left(\mathrm{x}^{2}=11.702, \mathrm{df}\right.$ $=2, p=.003$ ). Also observed was a dramatic increase in the number of advertisements mentioning the ability to work collaboratively or in teams, from no cases in 1970-89 to 16 (47.1 percent) in 2000-2007. This relationship was statistically significant $\left(\mathrm{x}^{2}=22.276, \mathrm{df}=2, p=.000\right)$. In addition to expecting applicants to work well with other employees, the advertisements stipulated that the applicant have a usercentered perspective. Only 3 cases (12 percent) appeared in 1970-89 mentioning this trait, while 13 (38.2 percent) were published in 2000-2007. The remaining personal traits, including the ability to work in a changing environment, in a multicultural environment, and independently, were less frequently observed in the job postings, with only 8 cases (8.5 percent) containing each of these traits. The latter 2 traits show an increase in frequency over time, particularly in 2000-2007.

\section{Duties and Subject Responsibilities}

Duties define the daily work of a position (see section C of the appendix for study findings). By design, collection development was an expected duty in all cases. Several other duties are related to collection development activities. Of those, the most frequently occurring duty mentioned in the advertisements was managing collection budgets, which was listed in 29 instances of the 94 positions ( 30.9 percent). The number of positions requiring this variable grew from 3 
cases (12 percent) in 1970-89 period to 7 cases (20 percent) in 1990-99 and 19 cases (55.9 percent) in 2000-2007. This increase is statistically significant $\left(\mathrm{x}^{2}=16.082, \mathrm{df}=2, p=\right.$ $.000)$.

Three specific methods of adding materials to the collection were mentioned in the advertisements, and data show a steady growth in their appearance over time. Gifts and exchange program duties were included in 17 cases (18.1 percent). Only 1 of the postings (4 percent) published in 1970-89 mentioned gifts and exchange programs, while 10 cases (29.4 percent) mentioning this appeared in 20002007. Two duties, approval and blanket plans and cooperative collection development, were included in 11 cases (11.7 percent). In 1970-89, only 1 position (4 percent) included approval and blanket plans, while in 2000-2007 this duty was stated in 8 cases (23.5 percent). In 1970-89, only 1 case (4 percent) mentioned cooperative collection development, which increased to 5 cases (14.7 percent) in 2000-2007.

Closely related to collection development for subject specialists is the function of liaison, which involves outreach and interaction with individuals in LACS studies centers, programs, and departments. More than half (56.4 percent) of the job advertisements mentioned liaison as a duty. Another duty is community outreach, which differs from liaison in that it involves initiatives that aim to reach the general public. Only 6 advertisements (6.4 percent) listed community outreach as a duty.

Other methods of library outreach and promotion assigned to subject specialists include involvement in various in-house library publications and special projects, such as exhibits and on-campus events. A total of 24 cases (25.5 percent) specified library publications as a duty, which increased from 2 advertisements (8 percent) in 1970-89 to 12 (34.3 percent) in the 1990s. Ten job announcements (10.6 percent) stated that participation in special projects was a position duty.

LACS librarians, as subject experts, traditionally have provided specialized reference and research service. Increasingly, they have been providing general reference as part of their duties. Of the 94 job announcements, 63 (67 percent) mentioned specialized reference, with growth from 14 cases (56 percent) in 1970-89 to 24 cases (70.6 percent) in 2000-2007. A total of 52 postings (55.3 percent) listed general reference as a position duty. In 1970-89, 13 cases (52 percent) mentioned this duty, and 21 advertisements (61.8 percent) specified general reference in 2000-2007.

Universities have recognized the role of the librarian as an educator, as shown by the growth of information literacy and instruction programs. In particular, course-integrated instruction has become more prevalent as a natural outgrowth of their liaison activities. For subject specialists, information literacy often involves course- or disciplinerelated instruction. Of the 94 advertisements, 54 (57.4 percent) listed instruction as a job duty, with 12 of the cases
(48 percent) appearing in 1970-89 and 22 (64.7 percent) in 2000-2007. In some instances, instruction may include teaching credit-bearing courses. Only 7 advertisements (7.4 percent) included teaching these courses as a duty.

The prevalence of course-related instruction can be seen in the Association for College and Research Libraries' 2003 Academic Library Trends and Statistics for Carnegie Classification: Doctorate-Granting Institutions. ${ }^{30}$ More than 91 percent of institutions in this category state that they provide library presentations that are developed in collaboration with course instructors and are tailored to course objectives. Also, librarians and faculty have developed information literacy instruction taught as an integral part of some courses in 73.9 percent of these institutions. These ACRL statistics are pertinent because more than 95 percent of the academic library job advertisements in the present study are from doctoral degree-granting institutions. The independent variable institution type affects the variable information literacy in a statistically significant manner $\left(x^{2}=12.186\right.$, $\mathrm{df}=2, p=.002)$. A higher percentage of advertisements from private institutions (75 percent) included information literacy as a duty. The percentage (60.7 percent) for public institutions is higher than for research and specialized libraries (15.4 percent).

Librarians are often expected to have a service component to their positions. Service can encompass both working on committees within the library and representing the library in external professional associations, consortia, and projects. A total of 40 position announcements (42.6 percent) specified service as a job duty. In 1970-89, 7 cases (28 percent) listed service as a duty, while in 2000-2007 the number had increased to 21 cases (61.8 percent). The relationship between service and time period was statistically significant $\left(\mathrm{x}^{2}=8.278, \mathrm{df}=2, p=.016\right)$.

Along with effectiveness in librarianship and service, some academic libraries expect librarians to undertake research activities. Only 7 of the cases (7.4 percent) under study included research as a job duty.

In addition to library-specific duties, job advertisements also call for more generic managerial, administrative, and technology skills. The category of administrative and management duties includes cases that specify such activities as "planning," "implementation," and "direction," while some advertisements mentioned only "supervision," which is included as its own category. Of the 94 total positions, 26 (27.7 percent) required administrative and management skills; this increased over time from 3 cases (12 percent) in $1970-89$ to 12 (35.3 percent) in 2000-2007. Supervision includes directing the work of students, staff, or other librarians, and was requested in 28 cases (29.8 percent). Over time, there was an increase from 7 cases (28 percent) in $1970-89$ to 12 cases (35.3 percent) in 2000-2007. Only 15 advertisements (16 percent) mentioned grant writing and development as a duty, but the frequency increased from 
only 1 position (4 percent) in $1970-89$ to 8 (23.5 percent) in 2000-2007.

Several different technology skills were sought in job announcements. The most highly sought were online searching, which was mentioned in 13 instances (13.8 percent), and creation of subject-based webpages, requested in 10 cases (10.6 percent). The growing presence of the Internet in the daily work of bibliographers is reflected in the increase in the job announcements that required the creation of subject-based webpages. This skill first appeared in only 1 advertisement (2.9 percent) in 1990-99 and was present in 9 cases (26.5 percent) in 2000-2007. The inclusion of online searching as a requirement peaked in the 1990s, with 7 instances (20 percent).

Other duties that appeared in a smaller number of cases were cataloging (11), work with vendors (8), acquisitions (6), acquisition trips (3), and archives (1).

The heart of a bibliographer's job is subject responsibility. The 82 job postings ( 87.2 percent) that included LACS as a whole formed the basis of the present study. However, an additional 12 advertisements were specific to certain countries or territories within Latin America and the Caribbean, including Cuba, Mexico, Brazil, Puerto Rico, and the Dominican Republic.

Iberian studies was the second most frequently occurring responsibility, with 42 cases (44.7 percent). This variable includes instances that mention both Spanish and Portuguese studies. From 1970-89 to 1990-99, the percentage of advertisements that included Iberian studies increased from 8 cases (32 percent) to 18 (51.4 percent).

Spanish and Portuguese language and literature appeared with similar frequencies, 17 (18.1 percent) and 16 cases (17 percent) respectively. The Spanish language and literature variable (section $\mathrm{C}$ in the appendix) includes bibliographer positions that serve Spanish or Hispanic studies academic departments and programs. This may include language and literature from both Spain and Latin America. Similarly, the Portuguese language and literature variable includes positions that support Portuguese academic departments and programs. This may include language and literature from both Brazil and Portugal. Another frequently occurring subject responsibility was U.S. Latino studies, which was included in 11 advertisements (11.7 percent). This variable also includes positions that mention Mexican American or Chicano studies.

\section{Discussion}

The role of the traditional LACS bibliographer, reflected even in the title of the position, has changed over time. Today's subject specialist is more likely to have the title of librarian, which is a broader title encompassing more duties and responsibilities than just collection development, which was common in the past.

The majority of openings have been in public universities throughout the United States. The only positions specifically mentioning faculty status and tenure track were located at public universities. Ascertaining the scope and implications of faculty status simply by reading the position announcements is difficult. Terms such as faculty and professional mean different things at different institutions. Without knowing the institutional promotion and tenure requirements and faculty status policies of a particular institution, determining the responsibilities and expectations associated with these terms is impossible.

Public universities tended to be more forthcoming than private colleges or specialized libraries concerning salary information, with 71.6 percent of the cases that included salary information being from public universities. Still, because most advertisements listed only minimum salaries or salary ranges or stated that salary was commensurate with experience, looking at published salary surveys for this type of data would be informative.

\section{Academic Background}

The importance of the MLS has been widely debated. Grimes and Grimes examined position descriptions for professional academic library jobs appearing from 1975 through 2005 to determine the extent to which the MLS was a prerequisite for employment. ${ }^{31}$ This study included all professional positions, including systems and administrative jobs. They found the highest proportion of job announcements that required an MLS appeared in the early 1990s. This dropped off in later years, and the decrease was particularly dramatic in 2005. In contrast, the present study showed a small increase in the MLS requirement over time. When Grimes and Grimes categorized the advertisements by job function, they found that the MLS requirement remained important for certain types of jobs. They reported that "results suggest that the MLS is important for libraries when hiring workers to perform core functions in public and technical services. ${ }^{\text {"32 }}$ Findings from the research reported here suggest that the MLS remains important for LACS librarians, who perform some of these core public services functions, including collection development, reference, instruction, and liaison work. However, this degree is not an absolute requirement for positions in specialized libraries, which may be open to more diverse educational backgrounds.

The research reported in this paper suggests that the ideal educational background for a LACS librarian is an MLS and also a master's degree in a field related to Latin American studies. Job advertisements do not often specify having an undergraduate degree in a related field. An advanced degree in a relevant subject area is valued by both public and private universities, but it is more often a preference than a requirement. Of all the job postings that required an MLS, 
33.8 percent required an advanced degree, and an additional 33.8 percent preferred an advanced degree. All of the tenure track positions specifically required an ALA-accredited MLS, and all of the cases in which the position had faculty status required or preferred an ALA-accredited MLS.

Only 17 cases (18 percent) did not require, prefer, or mention an MLS or a subject degree in the advertisement. These positions were largely in private universities or research centers. Omitting strict educational requirements in the announcement allows an institution more flexibility in screening a more diversified pool of applicants. As Block stated, "Vagueness allows for wide latitudes in hiring in a buyers' market." ${ }^{\prime 33}$ In the past, efforts have been made to attract $\mathrm{PhDs}$ to the field of librarianship. Only 17 cases mentioned holding a $\mathrm{PhD}$. Of those, all but 2 stated that the $\mathrm{PhD}$ is preferred rather than required. Duke University's post-doctoral fellowship program, which ran from 1995 to 2001, focused on training $\mathrm{PhD}$ recipients in any field of Latin American studies as research librarians. This program did not require the participants with $\mathrm{PhDs}$ to obtain an MLS, but instead trained them about research libraries to complement their extensive subject knowledge. While the individuals completing this program were successfully placed in library positions, the data do not suggest a substantial increase in employer demand for the $\mathrm{PhD}$ as a requirement. A 2008 article by Lindquist and Gilman surveying academic librarians who hold subject doctorates found that only 4 percent were in area studies. ${ }^{34}$ How many of those were in Latin American studies is not known.

Detlefsen, in her analysis of job listings for subject specialist librarian positions, suggested the creation of an "Executive MLS" degree for qualified individuals as an alternative to the traditional MLS. ${ }^{35}$ The Executive MLS would be a condensed program, patterned after the popular executive MBA degrees offered by many business schools. In this way, people with strong subject backgrounds and familiarity with research practices or those who have worked in libraries could obtain professional positions without the time and expense involved in taking a traditional MLS program. This type of program might be attractive to individuals highly educated in the field of Latin American studies.

\section{Work Experience}

While having experience in many aspects of library service is seen as a positive attribute in a prospective candidate, those with experience in certain library tasks were more sought after than others by employers. Nearly half of the job postings (46.8 percent) included "experience in collection development" as required or preferred. Since all the positions examined in the study were for collection development librarians, that this type of experience does not appear more frequently is surprising. Employers may wish to expand the applicant pool by omitting this requirement or be willing to train the successful candidate.

In the case of reference and instruction, the numbers are even lower. Of the job announcements where general or specialized reference is a duty, only 32.7 percent and 27 percent respectively required or preferred experience performing it. Similarly, when instruction is a duty, only 25.9 percent of job advertisements required or preferred experience in it.

When different types of experience were mentioned in the advertisements, the amount of experience was seldom quantified. However, the majority of the jobs that required four or more years of experience in research or academic libraries were offered in 2000-2007. This was a relatively small number of positions (going from none in 1970-89 to 7 in 2000-2007). The increase in the director and head types of positions may be because of the retirement of professionals at this level.

\section{Technology Skills}

Given the tremendous influence of technological developments on library services, collections, and work patterns, one might expect that job advertisements posted in the late 1980s through 2007 would be replete with specific technological proficiency requirements. Contrary to the authors' expectations, not many of these job advertisements mentioned skills like working with digital projects, creating Web-based subject guides, or designing and maintaining websites. A plausible explanation was offered by $\mathrm{Xu}$, who noted that "there is a time gap from the implementation of new technology in libraries to the corresponding changes in library professional duties and responsibilities.... However, requirements concerning the knowledge of such relevant skills did not immediately appear in job advertisements. ${ }^{, 36}$ Also largely absent from more recent job announcements were skills like online searching, which were more prevalent in the 1990s. A possible explanation for the absence of online searching is also offered by $\mathrm{Xu}$, who observed that because "certain sorts of requirements or responsibilities have become relatively commonplace, they might not always be mentioned in the job descriptions. ${ }^{377}$ Lynch and Smith noted that, "because the ALA-accredited degree is an accepted job requirement, the assumption of employers seems to be that a graduate's knowledge base will include knowledge of computer technologies as they relate to library and information science." ${ }^{, 38}$

\section{Languages}

Little research has been undertaken into the requirement for area studies librarians to hold foreign language skills. Zhang used content analysis to examine academic librarian job postings from 1966 to $2006 .{ }^{39}$ Zhang's analysis included a category for "bibliographer and area studies librarians" 
positions. This category showed a substantial increase in the demand for foreign language skills from 1966 to 1991. This is consistent with data in the present study for Spanish and Portuguese language skills. After that time, Zhang found a slight decrease in the number of job advertisements requiring foreign language skills. In contrast to Zhang's data, the current study showed that growth for Spanish and Portuguese skills as a requirement leveled off in the 1990s and throughout 2000-2007. One possibility for this disparity is that Zhang's category included bibliographer positions, for which language skills would not be expected to be of importance.

The requirement for English language skills showed a different trend in this study. While relatively few advertisements mentioned a requirement for English, data show a steady growth in the number of occurrences, from 4 percent in $1970-89$ to 29.4 percent in $2000-2007$. Not only did the numbers increase, but the requirement was for fluency in English in all cases. Perhaps in the earlier years English language skills could be assumed by employers. In later time periods, with a more globalized applicant pool, employers apparently felt the need to explicitly mention fluent English as a requirement.

One of the questions the authors sought to explore was, Were some subject responsibilities and languages commonly found together? The relationship was very strong between Spanish language ability and Iberian studies, Latin American and Caribbean studies, Portuguese language and literature, Spanish language and literature, and U.S. Latino studies. More than 90 percent of the job postings including these subjects required Spanish language ability, with the exception of U.S. Latino studies, in which more than 70 percent of the advertisements required it. Portuguese language ability was also an asset. Nearly half of the job announcements with LACS responsibilities specified having Portuguese language skills as a requirement. In the case of Iberian studies responsibilities, 59.5 percent of the advertisements required Portuguese language skills.

\section{Duties}

With the creation of subject specialist positions within the library, Byrd and Haro recognized core duties for subject librarians that encompassed traditional collection development responsibilities as well as specialized reference, instruction, and liaison responsibilities. ${ }^{40}$ Robinson, in his examination of job advertisements for collection development positions from 1980 to 1991, identified a number of additional expected duties, including online searching and resource sharing. ${ }^{41}$ White looked at subject specialist positions advertised from 1990 to $1998 .^{42}$ His analysis found a basic set of highly ranked core duties as identified by Byrd, Robinson, and Haro, with additional technical and managerial responsibilities for the positions.
The position of LACS librarian includes a wide range of duties. The number of duties per advertisement ranged from 1 to 14. The overall average of duties per job advertisement was 6.44. Over time, the number of duties has increased, from an average of 4.8 duties in 1970-89 to 6.25 in 1990-99 and 7.85 in 2000-2007. These figures reflect the evolution of the LACS librarian profile from a narrowly focused specialist with a limited number of duties to a more diversified and multitasking librarian. Given the added workload associated with providing new services and electronic resources, often coupled with staffing constraints, the fact that collection development librarians are undertaking additional duties is not surprising.

Some differences were seen in job duties at public and private institutions. Public universities are more likely to include general reference as a job duty (62.3 percent) than are private universities (35 percent). Both types of institutions are highly likely to state that specialized reference is a duty, with the requirement being slightly higher in private universities (75 percent) than public universities (67.2 percent). Activities such as research and publication are closely associated with the issue of faculty status or tenure. None of the jobs advertised by private universities listed research as a requirement, nor were any positions identified as being tenure track or having faculty status. While the total number of positions that included research or publication as a job duty was small—only 7 cases ( 11.5 percent —all of them occurred at public institutions. Service as a duty often also is associated with requirements for promotion and tenure, but it is also a required duty for many other nontenure track librarian positions. Applicants can anticipate that service, such as committee work and participation in professional organizations, may be required at both public and private institutions (39.9 and 60 percent respectively).

In particular, the demand for the ability to manage collection budgets is growing. This trend was also observed by Haar, who noted, "Its presence may be another sign that stretching ever more precious dollars is a growing concern among libraries." ${ }^{43}$ Haar found a growing demand for general reference service, a trend also seen in the present study. Robinson noted the trend toward combined positions and away from jobs that were full-time collection development only; nearly 80 percent of the combined positions in his study involved reference work. ${ }^{44}$

Collaborative collection development is another way to leverage tight collection budgets and simultaneously expand collections and services. The library literature has widely discussed this issue. Jakubs has observed an "increased focus on cooperation and collaboration in libraries." ${ }^{\prime 45}$ Hazen has predicted that cooperative endeavors will increase in the future. ${ }^{46}$ The Spec Kit Collaborative Collections Management Programs in ARL Libraries considered these programs commonplace, noting that collaborative collection development programs occur more 
frequently in the field of area studies. ${ }^{47}$

While relatively few job postings specifically mentioned cooperative collection development as a duty, it is fairly common on the job. This is evidenced by initiatives such as the Latin American Research Resources Project (http:// lanic.utexas.edu/larrp), currently including 57 participating libraries. This projects calls for LACS librarians with leadership skills, experience in teamwork, and a deep knowledge of collection strengths and weaknesses.

The data also reflected a moderate but growing call for working with approval plans, which may be a reflection of the increased demands on the bibliographer's time from myriad other duties in addition to collection development. In some cases, the LACS librarian may be responsible for collecting in areas outside his or her field of expertise, and relying on an approval plan may be a convenient way to fill specific needs within the collection.

While the diversity and number of duties listed in a job advertisement may seem daunting to a potential applicant, few employers seem to expect experience with all or even most of the duties listed. If a prospective employee is looking to get experience in a particular duty, collection development, reference, and instruction (in that order) likely would make them more marketable.

Some duties were more commonly found together than others. Chi-square values for the most commonly occurring duties presented in section $\mathrm{C}$ of the appendix were calculated to determine if the relationships between them were statistically significant. The results are given in table 2 . The core duties typically performed by the bibliographer tended to be associated with a larger number of other duties: specialized reference, instruction, liaison work, and collection budget management. Applicants should expect to find these duties together. Because collection development was a constant for these advertisements, it was not included in the analysis of duties. The creation of library publications as a duty showed no statistically significant relationship with any other duty.

\section{Subject Responsibilities}

In contrast to the growth seen in the number of duties, the number of subject responsibilities has remained fairly constant over time. Job announcements had an average of 2.31 subject responsibilities. The number of subject responsibilities per advertisement ranged from 1 to 8 .

The most prevalent combination of subject responsibilities was Latin American studies and Iberian studies; both were included in 42.6 percent of the total job advertisements. This relationship was statistically significant $\left(\mathrm{x}^{2}=\right.$ $4.368, \mathrm{df}=1, p=.037$ ). This association shows that a LACS librarian has a good chance of also having Iberian studies responsibilities because Latin America and Iberia share a common language, history, and culture. The next most commonly occurring combination was that of Latin American studies and Spanish language and literature, found in 18.1 percent of the total job announcements, followed by Portuguese language and literature and Latin American studies, found in 14.9 percent.

As more U.S. universities have implemented Latino studies programs as part of a growing interest in the study of immigrant populations, one would expect that many LACS position postings would have included this subject responsibility, but only 10.6 percent of the cases examined included both Latin American and U.S. Latino studies. However, announcements for positions such as Chicano studies, ethnic studies, or diversity librarians are not included because the focus in this study was job advertisements with subject responsibility in Latin American and Caribbean studies or a country or territory within it.

\section{Summary and Conclusions}

A distillation of the job announcements yields a picture of the typical LACS librarian. In terms of educational background, an MLS is standard and an advanced degree in a related subject field is highly desirable. Prior experience in an academic or research library, particularly in collection development, is sought by employers. Experience performing reference and library instruction is also valued. General technology skills are commonly expected. Strong Spanish language abilities are required, and at least a working or reading knowledge of Portuguese is highly desirable. In today's work environment, excellent communication skills are essential. Related traits such as interpersonal skills, the ability to work in teams, and a public service orientation are expected. In addition to performing collection development, the LACS librarian will be responsible for reference (both general and specialized), library instruction, and liaison with academic departments, programs, and centers. The LACS librarian also may be assigned additional subject responsibilities, including Iberian studies, Spanish and Portuguese language and literature, or U.S. Latino studies.

The LACS librarian is now expected to undertake a wider range of duties than in the past, and this trend will likely continue in the future. As technology continues to transform the workplace, librarians are expected to expand electronic offerings and services. For example, chat and text messaging reference are offered by many libraries. Collection development now encompasses technologies like streaming video and electronic books, which require additional selection, evaluation, and management skills. These technologies also affect the library instruction process as librarians are often asked to teach students and faculty how to make the best use of the powerful and sophisticated added features offered with many electronic resources.

Academic and research libraries are facing difficult budgetary times. The cost of materials has outpaced the overall 
Table 2. Associations between Duties

\begin{tabular}{|c|c|c|c|}
\hline \multirow[t]{2}{*}{ Duty } & \multirow[t]{2}{*}{ Associated Duties } & \multicolumn{2}{|c|}{$\begin{array}{l}\text { Chi-square } \\
\text { value }(\mathrm{df}=1)\end{array}$} \\
\hline & & $x^{2}$ & $p$ \\
\hline \multirow{3}{*}{$\begin{array}{l}\text { Reference } \\
\text { (specialized) }\end{array}$} & Instruction (information literacy) & 23.002 & .000 \\
\hline & Liaison & 3.926 & .048 \\
\hline & Reference (general) & 20.057 & .000 \\
\hline \multirow{3}{*}{$\begin{array}{l}\text { Instruction } \\
\text { (information literacy) }\end{array}$} & Reference (specialized) & 23.002 & .000 \\
\hline & Liaison & 19.708 & .000 \\
\hline & Reference (general) & 11.631 & .001 \\
\hline \multirow{3}{*}{ Liaison } & Reference (specialized) & 3.926 & .048 \\
\hline & Instruction (information literacy) & 19.708 & .000 \\
\hline & Service & 9.813 & .002 \\
\hline \multirow{3}{*}{$\begin{array}{l}\text { Manage collection } \\
\text { budget }\end{array}$} & Service & 15.297 & .000 \\
\hline & Supervision & 16.671 & .000 \\
\hline & Administrative/management & 12.138 & .000 \\
\hline \multirow{2}{*}{ Reference (general) } & Reference (specialized) & 20.057 & .000 \\
\hline & Instruction (information literacy) & 11.631 & .001 \\
\hline \multirow{2}{*}{ Service } & Liaison & 9.813 & .002 \\
\hline & Manage collection budget & 15.297 & .000 \\
\hline \multirow{2}{*}{ Supervision } & Manage collection budget & 16.671 & .000 \\
\hline & Administrative/management & 38.181 & .000 \\
\hline \multirow{2}{*}{$\begin{array}{l}\text { Administration/ } \\
\text { management }\end{array}$} & Manage collection budget & 12.138 & .000 \\
\hline & Supervision & 38.181 & .000 \\
\hline
\end{tabular}

electronicjobadvertisements for research purposes.... It would be fitting if the leading professional journals of our field took steps to facilitate research about librarianship by electronically archiving librarian positions announcements in addition to other content." ${ }^{48}$ The LALA-L distribution list is only open to SALALM members. However, since 2007, a public archive of job and internship postings is maintained as part of the SALALM website (http:/library.lib .binghamton.edu/salalm/news/jobs.html), which will help facilitate this type of research in the future. Of particular importance to the study of academic library job advertisements would be the creation of an electronic archive of positions advertised in the Chronicle of Higher Education. This would provide access to a larger universe of advertisements, which would enable more robust research to allow stronger generalizations to ascertain findings and trends.

One limitation of the content analysis method as applied to job advertisements is that it does not necessarily reflect the actual work experience of individuals employed in this field. A survey study of those librarians actually hired for those positions would give a more detailed picture of the current profile of this type of employment.

To complement the study of the LACS librarian, the question of how well existing library science programs prepare students for these positions also should be examined. A study of current course offerings would reveal any disparities between what

rate of inflation for several years and simultaneously the volume of materials published has grown explosively. This adds to the scope of duties expected from bibliographers as libraries are often loath to cut services but may not be able to replace staff. In times of constrained collections budgets, open-access materials offer one way to provide information. For LACS librarians, identifying and promoting open-access materials to students and faculty who may be unaware of them present additional challenges.

While the data do not show a parallel growth in subject responsibilities over time, one can logically expect expansion in that area in the future. One explanation could be that bibliographers are being assigned more subject responsibilities after they are hired. This could be confirmed by a survey study of bibliographers who have been employed in their current positions for some time.

Content analysis provides a rich source of data about what employers seek in LACS librarian positions. Increasingly, libraries publish job announcements only electronically. This presents a challenge for studying these postings because they are often retained for only a limited time period. As Kinkus noted, "To this end, it would be useful if reputable library science journals such as $C \downarrow R L$ News and American Libraries maintained an archive of students are being taught and what employers are requiring. This type of study could provide opportunities to tailor the curriculum to better prepare students to gain employment.

Because LACS librarianship is a highly specialized field, the number of job advertisements is limited. By expanding the universe of position announcements to include all area studies positions, such as Asian studies or Africana studies, one could gain a broader picture of the scope of area studies positions and also compare differences and similarities among them. As globalization studies gains recognition in academic programs, it may affect the scope of the traditional area studies positions. Likewise, comparative studies of different regions, such as East Asia and Latin America could reshape the definition of area studies positions in the future.

\section{References}

1. Eric Hershberg et al., "Open Letter to Senator Barack Obama From A Group of Scholars Specializing in Latin America," Alliance for Responsible Trade, www.art-us.org/node/382 (accessed Nov. 11, 2008).

2. Eduardo Lozano and Carmelo Mesa-Lago, "Latin American Area Studies and Library Resources: A Challenge for Survival," in Twenty-Second Seminar on the Acquisition of Latin American Library Materials (SALALM). Final Report 
and Working Papers, June 12-17, 1977, ed. Anne H. Jordan (Austin, Tex.: SALALM Secretariat, 1979): 138.

3. The College Blue Book: Degrees Offered by Colleges and Subjects, 14th ed. (New York: CCM, 1972): 554-55; The College Blue Book: Degrees Offered by Colleges and Subjects, 28th ed. (New York: Macmillan, 2001), 851-52; The College Bhe Book: Degrees Offered by Colleges and Subjects, 36th ed. (Detroit: Macmillan, 2009), 1247-49.

4. U.S. Department of Education, National Center for Education Statistics, Chartbook of Degrees Conferred, 1969-70 to 1993-94, 106, http://nces.ed.gov/pubs98/98071 .pdf (accessed May 11, 2009); U.S. Department of Education, National Center for Education Statistics, Digest of Education Statistics 2008, Table 275: Bachelor's, Master's, and Doctor's Degrees Conferred by Degree-Granting Institutions, by Sex of Student and Discipline Division: 2006-07, 403, http://nces .ed.gov/pubs2009/2009020_3b.pdf (accessed May 11, 2009).

5. U.S. Census Bureau, "Hispanics in the United States," slide 4, www.census.gov/population/www/socdemo/hispanic/files/ Internet_Hispanic_in_US_2006.pdf (accessed Feb. 21, 2009).

6. CERLALC, El Espacio Iberoamericano del Libro 2008 (Bogotá, Colombia: CERLALC, 2008): 54.

7. Peter Stern, "The Growth of Latin American Studies and the American University," in The Role of the American Academic Library in International Programs, ed. Bruce D. Bonta and James G. Neal (Greenwich, Conn.: JAI Pr., 1992): 197.

8. Deborah Jakubs, "Staffing for Collection Development in the Electronic Environment: Toward a New Definition of Roles and Responsibilities," Journal of Library Administration 28, no. 4 (1999): 71.

9. Lynn Shirey, "Latin American Collections," in Building Area Studies Collections, ed. Dan C. Hazen and James H. Spohrer (Wiesbaden, Germany: Harrassowitz, 2007): 108-29.

10. Orchid Mazurkiewicz and Claude H. Potts, "Researching Latin America: A Survey of How the New Generation is Doing its Research," Latin American Research Review 42, no. 3 (Oct. 2007): 161-82.

11. Eldred R. Smith, "The Specialist Librarian in the Academic Research Library: The Role of the Area Studies Librarian," in Seventeenth Seminar on the Acquisition of Latin American Library Materials (SALALM). Final Report and Working Papers, June 11-14, 1972 (Amherst, Mass.: University of Massachusetts, 1975): 103-27.

12. Robert D Stueart, The Area Specialist Bibliographer: An Inquiry Into His Role (Metuchen, N.J.: Scarecrow, 1972).

13. Nancy J. Schmidt, ed., Future of Area Librarianship Conference. July 13-14, 1995: Proceedings (Bloomington: Indiana Univ. Libraries, 1997), https://scholarworks.iu.edu/ dspace/bitstream/2022/3052/1/Conference_Proceedings.pdf (accessed Nov. 10, 2008).

14. Kent E. Miller and Gilberto V. Fort, "Staffing of Latin America Research Collections in the United States," in Fourteenth Seminar on the Acquisition of Latin American Library Materials (SALALM). Final Report and Working Paper, June 17-20, 1969 (Washington, D.C: Organization of American States, 1970): 18-31.

15. Ronald Rayman, "Employment Opportunities for Academic Librarians in the 1970s: An Analysis of the Past Decade," College \& Research Libraries 42, no. 3 (May 1981): 229-34.
16. Mary Baier Wells, "Requirements and Benefits for Academic Librarians: 1959-1979," College \& Research Libraries 43, no. 6 (Nov. 1982): 450-58.

17. Joyce C. Wright, "Job Opportunities for Academic and Public Librarians: 1980-1984," Journal of Library Administration 9, no. 2 (1988): 45-58.

18. David W. Reser and Anita P. Schuneman, "The Academic Library Job Market: A Content Analysis Comparing Public and Technical Services," College \& Research Libraries 53, no. 1 (Jan. 1992): 49-59.

19. Penny M. Beile and Megan M. Adams, "Other Duties as Assigned: Emerging Trends in the Academic Library Job Market," College \& Research Libraries 61, no. 4 (July 2000): 336-47.

20. Beverly P. Lynch and Kimberly Robles Smith, "The Changing Nature of Work in Academic Libraries," College \& Research Libraries 62, no. 5 (Sept. 2001): 407-20.

21. Ibid., 416.

22. Joan Starr, "A Measure of Change: Comparing Library Job Advertisements of 1983 and 2003," LIBRES: Library and Information Science Research Electronic Journal 14, no. 2 (Sept. 2004), http://libres.curtin.edu.au/libres14n2/Starr_final .htm (accessed Oct. 2008).

23. William C. Robinson, "Academic Library Collection Development and Management Positions: Announcements in 'College \& Research Libraries News' from 1980 through 1991," Library Resources \& Technical Services 37, no. 2 (Apr. 1993): 134-46.

24. Gary W. White, "Academic Subject Specialist Positions in the United States: A Content Analysis of Announcements from 1990 through 1998," Journal of Academic Librarianship 25, no. 5 (Sept. 1999): 372-82.

25. John M. Haar, "Scholar or Librarian? How Academic Libraries' Dualistic Concept of the Bibliographer Affects Recruitment," Collection Building 12, no. 1/2 (1993): 18-23.

26. Sean P. Knowlton, The Future of Latin American Area Studies Librarianship (master's thesis, University of North Carolina), http://ils.unc.edu/MSpapers/2778.pdf (accessed Oct. 10, 2008).

27. Kimberly A. Neuendorf, The Content Analysis Guidebook (Thousand Oaks, Calif:: Sage, 2002): 1.

28. Sylvia D Hall-Ellis, "Descriptive Impressions of Entry-level Cataloger Positions as Reflected in American Libraries, AUTOCAT, and the Colorado State Library Jobline, 20002003," Cataloging \& Classification Quarterly 40, no. 2 (2005): $33-72$.

29. Haar, "Scholar or Librarian?" 18.

30. Association of College and Research Libraries, Academic Library Trends \& Statistics for Carnegie Classification: Doctorate-Granting Institutions (Chicago: ACRL, 2003).

31. Marybeth F. Grimes and Paul W. Grimes, "The Academic Librarian Labor Market and the Role of the Master of Library Science Degree: 1975 through 2005," Journal of Academic Librarianship 34, no. 4 (July 2008): 332-39.

32. Ibid., 338.

33. David Block, "Emerging Personnel Requirements in Academic Libraries as Reflected in Recent Position Announcements," 1980, Educational Resources Information Center, Identifier Number ED 215703, 15. 
34. Thea Lindquist and Todd Gilman, "Academic/Research Librarians with Subject Doctorates: Data and Trends 19652006," portal: Libraries \& the Academy 8, no. 1 (Jan. 2008): 31-52.

35. Ellen G. Detlefsen, "Specialists as Professionals in Research Libraries: An Overview of Trends and an Analysis of Job Announcements," Library Trends 41, no. 2 (Fall 1992): 187-97.

36. Hong $\mathrm{Xu}$, "The Impact of Automation on Job Requirements and Qualifications for Catalogers and Reference Librarians in Academic Libraries," Library Resources \& Technical Services 40, no. 1 (Jan. 1996): 10.

37. Ibid., 29.

38. Lynch and Smith, "The Changing Nature of Work in Academic Libraries," 417.

39. Li Zhang, "Foreign Language Skills and Academic Library Job Announcements: A Survey and Trends Analysis, 1966-2006," Journal of Academic Librarianship 34, no. 4 (July 2008): 322-31.

40. Cecil K. Byrd, "Subject Specialists in a University Library," College \& Research Libraries 27 (May 1966): 191-93; Robert
P. Haro, "The Bibliographer in the Academic Library," Library Resources \& Technical Services 13, no. 2 (Spring 1969): 163-69.

41. Robinson, "Academic Library Collection Development and Management Positions."

42. White, "Academic Subject Specialist Positions in the United States."

43. Haar, "Scholar or Librarian?" 21.

44. Robinson, "Academic Library Collection Development and Management Positions."

45. Jakubs, "Staffing for Collection Development in the Electronic Environment," 77.

46. Dan C. Hazen, "Twilight of the Gods? Bibliographers in the Electronic Age," Library Trends 48, no. 4 (Spring 2000): 821-41.

47. George J. Soete, Collaborative Collections Management Programs in ARL Libraries: A SPEC Kit (Washington, D.C.: Association of Research Libraries, 1998).

48. Jane Kinkus, "Project Management Skills: A Literature Review and Content Analysis of Librarian Position Announcements," College \& Research Libraries 68, no. 4 (July 2007): 362.

\section{Appendix. Change in Position Description Characteristics, Requirements, and Duties by Publication Period}

\section{A. POSITION DESCRIPTION CHARACTERISTICS}

\begin{tabular}{|c|c|c|c|c|c|c|c|c|}
\hline & \multicolumn{2}{|c|}{$\begin{array}{c}1970-89 \\
n=25\end{array}$} & \multicolumn{2}{|c|}{$\begin{array}{c}1990-99 \\
n=35\end{array}$} & \multicolumn{2}{|c|}{$\begin{array}{c}2000-2007 \\
n=34\end{array}$} & \multicolumn{2}{|c|}{$\begin{array}{l}\text { Total } \\
n=94\end{array}$} \\
\hline & $\#$ & $\%$ & $\#$ & $\%$ & $\#$ & $\%$ & $\#$ & $\%$ \\
\hline \multicolumn{9}{|l|}{ Job Title Category } \\
\hline Librarian & 6 & 24.0 & 18 & 51.4 & 22 & 64.7 & 46 & 48.9 \\
\hline Bibliographer & 11 & 44.0 & 7 & 20.0 & 3 & 8.8 & 21 & 22.3 \\
\hline Head/director & 3 & 12.0 & 6 & 17.1 & 5 & 14.7 & 14 & 14.9 \\
\hline Subject specialist & 5 & 20.0 & 4 & 11.4 & 1 & 2.9 & 10 & 10.6 \\
\hline Curator & 0 & 0.0 & 0 & 0.0 & 3 & 8.8 & 3 & 3.2 \\
\hline \multicolumn{9}{|l|}{ Institution Type } \\
\hline Public university & 22 & 88.0 & 20 & 57.1 & 19 & 55.9 & 61 & 64.9 \\
\hline Private university & 3 & 12.0 & 8 & 22.9 & 9 & 26.5 & 20 & 21.3 \\
\hline Research/specialized library & 0 & 0.0 & 7 & 20.0 & 6 & 17.6 & 13 & 13.8 \\
\hline ARL member library & 22 & 88.0 & 24 & 68.6 & 25 & 73.5 & 71 & 75.5 \\
\hline \multicolumn{9}{|l|}{ Geographic Location } \\
\hline South & 2 & 8.0 & 15 & 42.9 & 14 & 41.2 & 31 & 33.0 \\
\hline Northeast & 6 & 24.0 & 7 & 20.0 & 12 & 35.3 & 25 & 26.6 \\
\hline West & 11 & 44.0 & 5 & 14.3 & 4 & 11.8 & 20 & 21.3 \\
\hline Midwest & 6 & 24.0 & 8 & 22.9 & 4 & 11.8 & 18 & 19.1 \\
\hline Faculty Status & 6 & 24.0 & 5 & 14.3 & 3 & 8.8 & 14 & 14.9 \\
\hline Tenure Track & 4 & 16.0 & 8 & 22.9 & 5 & 14.7 & 17 & 18.1 \\
\hline \multicolumn{9}{|l|}{ Reporting Line } \\
\hline Other & 3 & 12.0 & 2 & 5.7 & 6 & 17.6 & 11 & 11.7 \\
\hline Area studies/international studies & 0 & 0.0 & 5 & 14.3 & 4 & 11.8 & 9 & 9.6 \\
\hline
\end{tabular}


A. POSITION DESCRIPTION CHARACTERISTICS (cont.)

Collection development

Public services (includes reference)

Latin American library/unit

\begin{tabular}{rrrrrrrr}
\multicolumn{2}{c}{$\begin{array}{c}1970-89 \\
n=25\end{array}$} & \multicolumn{2}{c}{$\begin{array}{c}1990-99 \\
n=35\end{array}$} & \multicolumn{2}{c}{$\mathbf{2 0 0 0 - 2 0 0 7}$} & \multicolumn{2}{c}{$\begin{array}{c}\text { Total } \\
\mathbf{n = 3 4}\end{array}$} \\
$\#$ & $\%$ & $\#$ & $\%$ & $\#$ & $\%$ & $\#$ & $\%$ \\
3 & 12.0 & 2 & 5.7 & 3 & 8.8 & 8 & 8.5 \\
0 & 0.0 & 2 & 5.7 & 3 & 8.8 & 5 & 5.3 \\
1 & 4.0 & 2 & 5.7 & 1 & 2.9 & 4 & 4.3 \\
23 & 92.0 & 32 & 91.4 & 19 & 55.9 & 74 & 78.7 \\
0 & 0.0 & 2 & 5.7 & 11 & 32.4 & 13 & 13.8
\end{tabular}

\section{B. REQUIREMENTS}

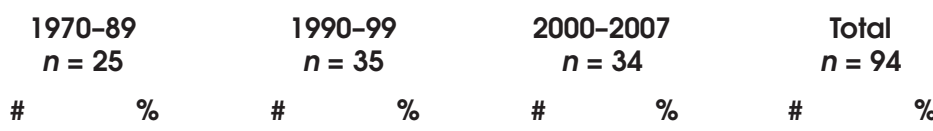

ACADEMIC BACKGROUND

\begin{tabular}{|c|c|c|c|c|c|c|c|c|}
\hline \multicolumn{9}{|l|}{ MLS } \\
\hline Required & 22 & 88.0 & 25 & 71.4 & 27 & 79.4 & 74 & 78.7 \\
\hline Preferred & 2 & 8.0 & 5 & 14.3 & 5 & 14.7 & 12 & 12.8 \\
\hline \multicolumn{9}{|c|}{ ALA-Accredited MLS } \\
\hline Required & 13 & 52.0 & 23 & 65.7 & 21 & 61.8 & 57 & 60.6 \\
\hline Preferred & 3 & 12.0 & 4 & 11.4 & 4 & 11.8 & 11 & 11.7 \\
\hline \multicolumn{9}{|c|}{ MLS Equivalent } \\
\hline Required & 5 & 20.0 & 8 & 22.9 & 9 & 26.5 & 22 & 23.4 \\
\hline Preferred & 2 & 8.0 & 1 & 2.9 & 0 & 0.0 & 3 & 3.2 \\
\hline \multicolumn{9}{|c|}{ Advanced Degree in a Related Field } \\
\hline Required & 6 & 24.0 & 11 & 31.4 & 11 & 32.4 & 28 & 29.8 \\
\hline Preferred & 8 & 32.0 & 14 & 40.0 & 13 & 38.2 & 35 & 37.2 \\
\hline \multicolumn{9}{|c|}{ Undergraduate Degree in a Related Field } \\
\hline Required & 4 & 16.0 & 5 & 14.3 & 3 & 8.8 & 12 & 12.8 \\
\hline Preferred & 2 & 8.0 & 0 & 0.0 & 1 & 2.9 & 3 & 3.2 \\
\hline \multicolumn{9}{|c|}{ Coursework in a Related Field } \\
\hline Required & 8 & 32.0 & 8 & 22.9 & 11 & 32.4 & 27 & 28.7 \\
\hline Preferred & 1 & 4.0 & 3 & 8.6 & 1 & 2.9 & 5 & 5.3 \\
\hline \multicolumn{9}{|c|}{ BACKGROUND KNOWLEDGE } \\
\hline \multicolumn{9}{|c|}{ Knowledge of Area, History, Culture, and Society } \\
\hline Required & 6 & 24.0 & 8 & 22.9 & 18 & 52.9 & 32 & 34.0 \\
\hline Preferred & 2 & 8.0 & 1 & 2.9 & 0 & 0.0 & 3 & 3.2 \\
\hline \multicolumn{9}{|c|}{ Knowledge of Specialized Reference Tools and Bibliography } \\
\hline Required & 2 & 8.0 & 5 & 14.3 & 8 & 23.5 & 15 & 16.0 \\
\hline Preferred & 1 & 4.0 & 0 & 0.0 & 1 & 2.9 & 2 & 2.1 \\
\hline \multicolumn{9}{|c|}{ Knowledge of Area Publishing Trade } \\
\hline Required & 3 & 12.0 & 12 & 34.3 & 15 & 44.1 & 30 & 31.9 \\
\hline Preferred & 3 & 12.0 & 0 & 0.0 & 3 & 8.8 & 6 & 6.4 \\
\hline
\end{tabular}




\section{B. REQUIREMENTS (cont.)}

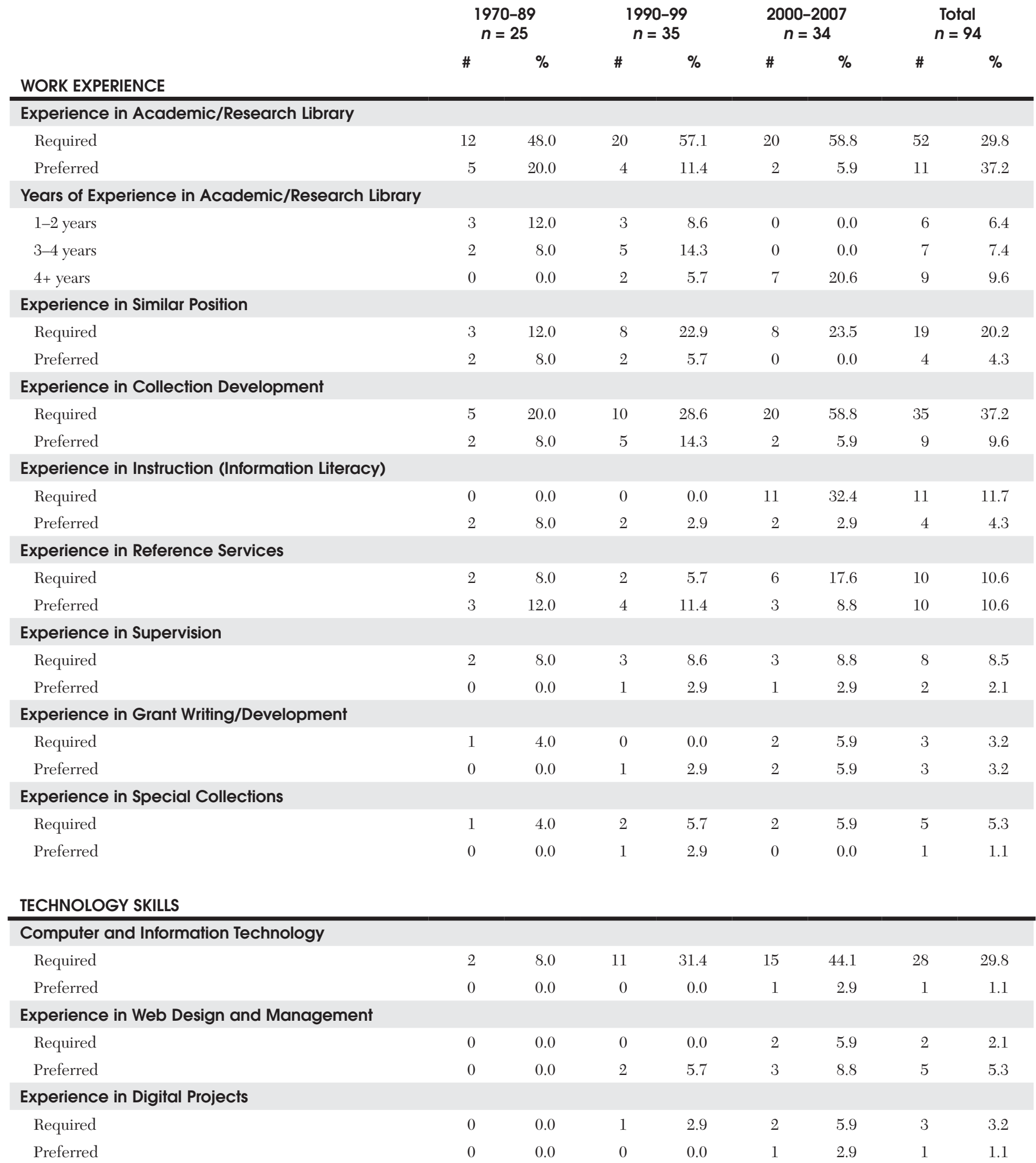




\section{B. REQUIREMENTS (cont.)}

\begin{tabular}{|c|c|c|c|c|c|c|c|c|}
\hline & \multicolumn{2}{|c|}{$\begin{array}{c}1970-89 \\
n=25\end{array}$} & \multicolumn{2}{|c|}{$\begin{array}{c}1990-99 \\
n=35\end{array}$} & \multicolumn{2}{|c|}{$\begin{array}{c}2000-2007 \\
n=34\end{array}$} & \multicolumn{2}{|c|}{$\begin{array}{c}\text { Total } \\
n=94\end{array}$} \\
\hline & $\#$ & $\%$ & $\#$ & $\%$ & $\#$ & $\%$ & $\#$ & $\%$ \\
\hline \multicolumn{9}{|c|}{ Experience in Online Searching } \\
\hline Required & 1 & 4.0 & 6 & 17.1 & 4 & 11.8 & 11 & 11.7 \\
\hline Preferred & 3 & 12.0 & 2 & 5.7 & 1 & 2.9 & 6 & 6.4 \\
\hline
\end{tabular}

\section{LANGUAGE SKILLS}

Spanish Language

Required

Preferred

$21 \quad 84.0$

$\begin{array}{lll}84.0 & 30 & 85.7\end{array}$

85.7

31

91.2

$82 \quad 87.2$

Spanish Language Skill Level

Fluent

Working knowledge

0.0

Reading knowledge

$\begin{array}{rrrrrrrr}16 & 64.0 & 25 & 71.4 & 30 & 88.2 & 71 & 75.5 \\ 2 & 8.0 & 4 & 11.4 & 2 & 5.9 & 8 & 8.5 \\ 3 & 12.0 & 3 & 8.6 & 0 & 0.0 & 6 & 6.4\end{array}$

\section{Portuguese Language}

Required
Preferred

$\begin{array}{rrrrrrrr}9 & 36.0 & 14 & 40.0 & 15 & 44.1 & 38 & 40.4 \\ 5 & 20.0 & 9 & 25.7 & 9 & 26.5 & 23 & 24.5\end{array}$

Portuguese Language Skill Level

\begin{tabular}{|c|c|c|c|c|c|c|c|c|}
\hline Fluent & 3 & 12.0 & 6 & 17.1 & 11 & 32.4 & 20 & 21.3 \\
\hline Working knowledge & 7 & 28.0 & 7 & 20.0 & 10 & 29.4 & 24 & 25.5 \\
\hline Reading knowledge & 4 & 16.0 & 10 & 28.6 & 3 & 8.8 & 17 & 18.1 \\
\hline \multicolumn{9}{|l|}{ English Language } \\
\hline Required & 1 & 4.0 & 6 & 17.1 & 10 & 29.4 & 17 & 18.1 \\
\hline Preferred & 0 & 0.0 & 0 & 0.0 & 0 & 0.0 & 0 & 0.0 \\
\hline \multicolumn{9}{|c|}{ English Language Skill Level } \\
\hline Fluent & 1 & 4.0 & 6 & 17.1 & 10 & 29.4 & 17 & 18.1 \\
\hline Working knowledge & 0 & 0.0 & 0 & 0.0 & 0 & 0.0 & 0 & 0.0 \\
\hline Reading knowledge & 0 & 0.0 & 0 & 0.0 & 0 & 0.0 & 0 & 0.0 \\
\hline \multicolumn{9}{|l|}{ French Language } \\
\hline Required & 2 & 8.0 & 1 & 2.9 & 3 & 8.8 & 6 & 6.4 \\
\hline Preferred & 3 & 12.0 & 4 & 11.4 & 2 & 5.9 & 9 & 9.6 \\
\hline \multicolumn{9}{|c|}{ French Language Skill Level } \\
\hline Fluent & 2 & 8.0 & 1 & 2.9 & 1 & 2.9 & 4 & 4.3 \\
\hline Working knowledge & 3 & 12.0 & 3 & 8.6 & 4 & 11.8 & 10 & 10.6 \\
\hline Reading knowledge & 0 & 0.0 & 1 & 2.9 & 0 & 0.0 & 1 & 1.1 \\
\hline \multicolumn{9}{|l|}{ Other Language(s) } \\
\hline Required & 1 & 4.0 & 3 & 8.6 & 3 & 8.8 & 7 & 7.4 \\
\hline Preferred & 9 & 36.0 & 3 & 8.6 & 3 & 8.8 & 15 & 16.0 \\
\hline \multicolumn{9}{|c|}{ Other Language(s) Skill Level } \\
\hline Fluent & 0 & 0.0 & 2 & 5.7 & 4 & 11.8 & 6 & 6.4 \\
\hline Working knowledge & 7 & 28.0 & 4 & 11.4 & 1 & 2.9 & 12 & 12.8 \\
\hline Reading knowledge & 2 & 8.0 & 0 & 0.0 & 1 & 2.9 & 3 & 3.2 \\
\hline
\end{tabular}




\section{B. REQUIREMENTS (cont.)}

\begin{tabular}{|c|c|c|c|c|c|c|c|c|}
\hline & \multicolumn{2}{|c|}{$\begin{array}{c}1970-89 \\
n=25\end{array}$} & \multicolumn{2}{|c|}{$\begin{array}{c}1990-99 \\
n=35\end{array}$} & \multicolumn{2}{|c|}{$\begin{array}{c}2000-2007 \\
n=34\end{array}$} & \multicolumn{2}{|c|}{$\begin{array}{l}\text { Total } \\
n=94\end{array}$} \\
\hline & $\#$ & $\%$ & \# & $\%$ & $\#$ & $\%$ & $\#$ & $\%$ \\
\hline \multicolumn{9}{|l|}{ PERSONAL TRAITS } \\
\hline Communication Skills (Oral \& Written) & 6 & 24.0 & 16 & 45.7 & 28 & 82.4 & 50 & 53.2 \\
\hline Interpersonal Relations & 2 & 8.0 & 11 & 31.4 & 17 & 50.0 & 30 & 31.9 \\
\hline Work Collaboratively/Teams & 0 & 0.0 & 4 & 11.4 & 16 & 47.1 & 20 & 21.3 \\
\hline Public Service Perspective (User-Centered) & 3 & 12.0 & 2 & 5.7 & 13 & 38.2 & 18 & 19.1 \\
\hline Changing Environment & 1 & 4.0 & 4 & 11.4 & 3 & 8.8 & 8 & 8.5 \\
\hline Multicultural Environment & 0 & 0.0 & 2 & 5.7 & 6 & 17.6 & 8 & 8.5 \\
\hline Work Independently (Self-Motivated) & 0 & 0.0 & 1 & 2.9 & 7 & 20.6 & 8 & 8.5 \\
\hline
\end{tabular}

\section{DUTIES AND SUBJECT RESPONSIBILITIES}

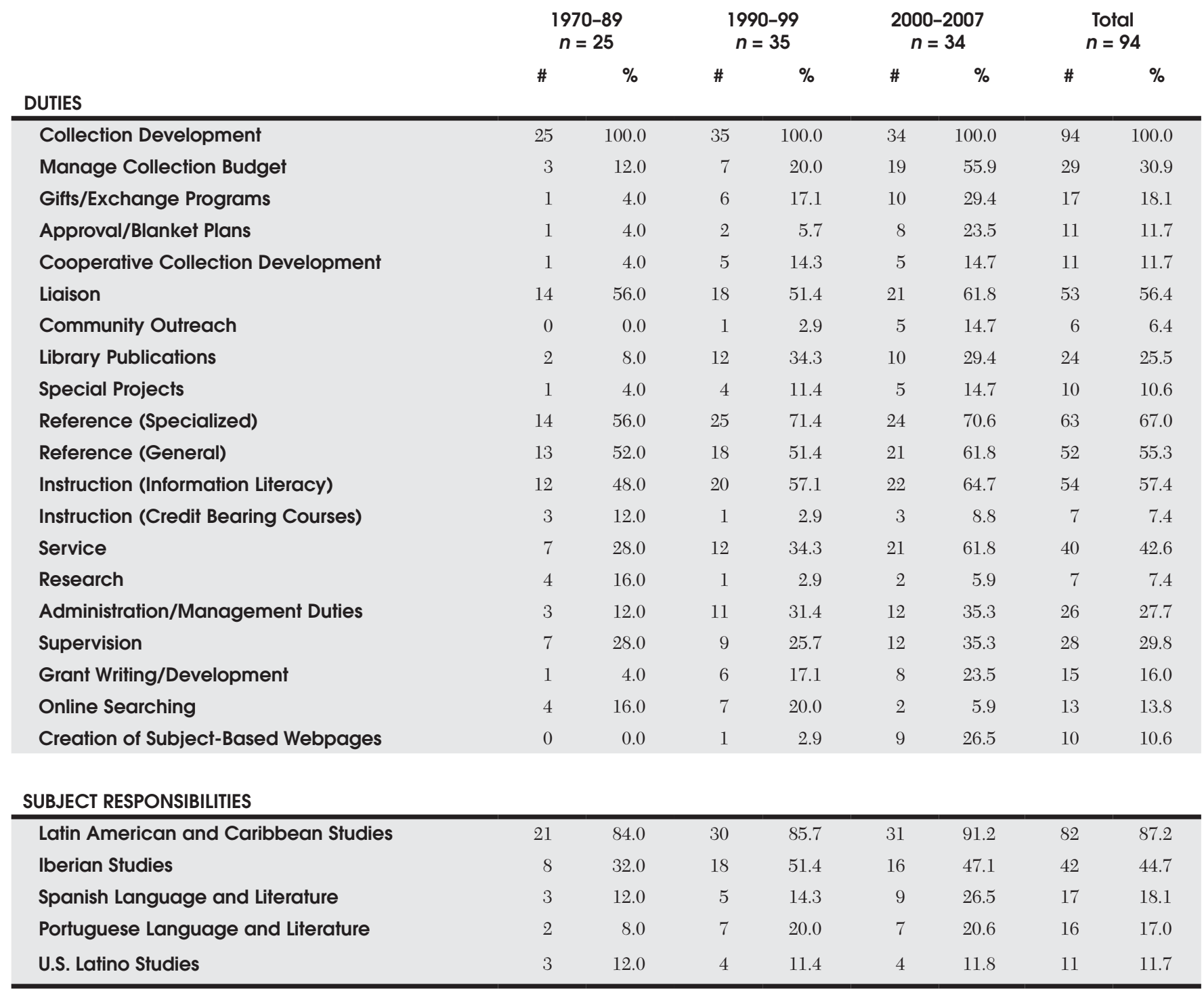

